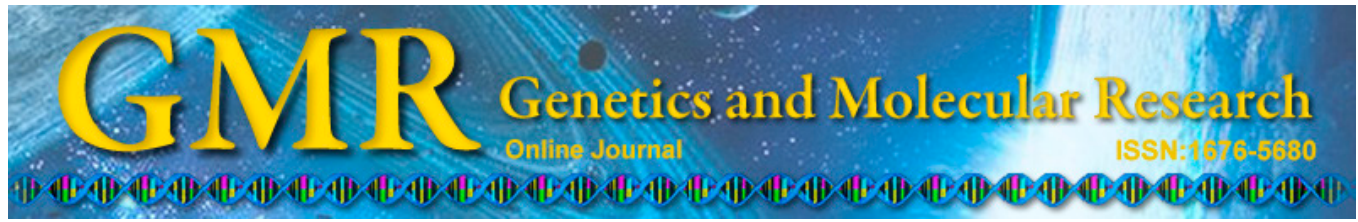

\title{
Relationship among physiological quality, heterosis, and amylase gene expression in maize seeds
}

\author{
G.E. Oliveira ${ }^{1}$, E.V.R. Von Pinho ${ }^{2}$, T. Andrade ${ }^{2}$, J.C. Souza ${ }^{1}$, F. Caixeta ${ }^{2}$ \\ and R.A.D.C. Ferreira ${ }^{1}$
}

${ }^{1}$ Departamento de Biologia, Universidade Federal de Lavras, Lavras, MG, Brasil ${ }^{2}$ Departamento de Agricultura, Universidade Federal de Lavras, Lavras, MG, Brasil

Corresponding author: T. Andrade

E-mail: thaisandradeagro@gmail.com

Genet. Mol. Res. 14 (3): 8623-8633 (2015)

Received September 12, 2014

Accepted March 12, 2015

Published July 31, 2015

DOI http://dx.doi.org/10.4238/2015.July.31.10

\begin{abstract}
In this study, we analyzed heterosis, amylase enzyme gene expression, and the physiological quality of maize seeds with different genotypes and sizes, which were subjected to aging and not subjected to aging. We used seeds from 2 maize lines that differed with regard to physiological quality, the hybrid, and the reciprocal hybrid; they were classified into 2 sizes and were subjected to aging and not subjected to aging. Physiological quality was assessed by performing tests for germination, emergence, emergence speed index, and artificial aging. Expressions of the genes alpha amylase B73, alpha amylase (LOC542522), isoamylase mRNA clone 353244, and the endogenous controls ubiquitin and alcohol dehydrogenase in the seeds were studied using quantitative real-time-polymerase chain reaction. We observed heterosis for seed quality and for expression of amylase genes in the
\end{abstract}


genotypes studied. We found no difference in seed quality between large and small seeds.

Key words: Quantitative real-time-polymerase chain reaction; Seed quality; Zea mays

\section{INTRODUCTION}

Crop breeding in maize is mainly based on hybrid generation because of hybrid vigor or heterosis. This phenomenon can be described as the superiority of the F1 progeny compared to the mean of its parents (Shull, 1908). Since the time of its discovery, heterosis has been intensively used to increase yield, biomass, early maturity, fertility, resistance to biotic and abiotic stresses, and many other traits, and has been widely studied. However, the genetic and molecular foundations of this phenomenon have not been well-established (Hallauer et al., 2010).

Previous studies have been carried out to examine hybrid vigor during germination (Gomes et al., 2000; José et al., 2004; Hoecker et al., 2006) and the initial stages of maize plant development (Hoecker et al., 2006). In several of these studies, hybrid plants were found to exhibit greater efficiency in the enzymatic systems than in the lines, explaining the greater seed vigor. According to Ding et al. (2012), microRNA repression in the hybrid, which results in greater efficiency in gene expression, may be one of the reasons why hybrids exhibit greater vigor in germination compared to parental lines.

In some studies, it was observed that a greater speed of germination and vigorous growth of seedlings were associated with greater metabolic activity of RNA, proteins, and DNA in the embryos (Fu and Dooner, 2002; Meyer et al., 2007; Guo et al, 2013; Jin et al., 2014). The authors also observed that in the hybrid embryo, the metabolism of proteins and lipids was greater than in the lines, favoring the growth of the embryonic axis and greater seed germination. Li et al. (2009) studied the profiles of gene expression among highly heterotic hybrids and their parents, as well as hybrids of low heterosis, and found that in both cases, there was greater gene expression than for their parents in relation to the traits assessed. Guo et al. (2013) identified 155 different proteins related to germination among the hybrids and their respective parents, showing that the hybridization between 2 lines may cause changes in the expression of various proteins. Thus, these changes in gene expression patterns in the hybrids may be responsible for the heterosis observed.

Biochemical studies showed that control of $\alpha$-amylase synthesis and subsequent hydrolysis of the seed reserves were related to gibberellins and heterosis in maize (Paleg, 1965). Rood and Larsen (1988) investigated the involvement of $\alpha$-amylase in heterosis in maize seedlings and observed that after $48 \mathrm{~h}$ of seed imbibition, enzyme activity in the hybrid seedlings was greater than that in their parental lines, as was the concentration of gibberellic acid, resulting in faster hydrolysis of maize starch.

According to Rood et al. (1990), maize lines have less vigor than their hybrid descendants, in part because of gibberellin deficiency. There was a positive correlation between the gibberellin content found in the seedlings and the increases in growth rate, leaf area, and plant height of maize. Fu et al. (2011) carried out proteomic analyses in seeds during germination and concluded that the capacity to repress abscisic acid in the hybrid seeds can in part explain the heterosis.

In addition, Oliveira et al. (2013) examined 4 maize lines and observed a high cor- 
relation between the expression of amylases and the physiological quality of seeds of maize lines. Andrade et al. (2013) found a highly positive correlation between the expression of heat-resistant proteins and the physiological quality of seeds, thus revealing the complexity of relating specific proteins to seed physiological qualities.

Moreover, some studies observed an effect of seed size on seed physiological quality (Von Pinho et al., 1995; Andrade et al., 1997; Oliveira et al., 2013); however, the results are controversial.

Therefore, we examined the expression of amylase enzymes and the heterosis of different genotypes and sizes of maize seeds subjected to aging and not subjected to aging and their association with physiological quality.

\section{MATERIAL AND METHODS}

The seeds were produced in the experimental unit of the Dow Agroscience company in the municipality of Castro, PR, Brazil. Physiological tests were performed in the seed laboratory of Dow Agroscience in the municipality of Ribeirão Preto, SP, Brazil, and quantitative real-time-polymerase chain reaction (qRT-PCR) analyses were conducted in the Central Seed Laboratory of the Universidade Federal de Lavras, municipality of Lavras, MG, Brazil.

We used seeds from 2 lines granted by the Dow Agroscience company. The lines differed in regard to quality, with one considered to be high-quality (P1) and the other to be low-quality (P2).

Initially, a field was established to multiply the seeds from the lines by self-pollination of the plants and by crosses to obtain the hybrid and reciprocal hybrid. This field was composed of 6 rows of 10-m length for each maize line, with $0.8 \mathrm{~m}$ spacing between rows. Fertilization, crop management, and crop treatments were carried out as recommended for the crop.

The ears were harvested manually when the seed moisture content reached approximately $25 \%$. The ears were husked manually and dried in an ear-corn dryer at a temperature of $35^{\circ} \mathrm{C}$ until the seeds reached $13 \%$ moisture. After drying and manual threshing, the seeds were classified by size in circular screen sieves and were grouped into seeds retained in the 20/64 and 22/64 sieves, called the large seeds, and those retained in the 18/64 and 16/64 sieves, called the small seeds.

After seed classification, the germination test was carried out to evaluate the initial quality of the seeds. The results showed that the seeds of all lines exhibited high physiological quality because the experimental conditions during their production phase were favorable. Thus, for selecting genotypes differing in regard to the physiological quality of the seeds, it was necessary to subject the seeds to artificial aging. The seeds were treated with the fungicide Vitavax $^{\circledR}$-Thiram $200 \mathrm{SC}$ at $250 \mathrm{~mL}$ for every $100 \mathrm{~kg}$ seeds. Aging was conducted using gerbox minichambers, in which the seeds were distributed over a screen suspended within the box containing $40 \mathrm{~mL}$ water and incubated at $41^{\circ} \mathrm{C}$ for $96 \mathrm{~h}$. Aged seeds were homogenized and dried in the shade at ambient temperature until reaching the initial moisture content of $13 \%$.

The physiological quality of the 4 lines was assessed by testing germination and first germination count (Brasil, 2009), seedling emergence, emergence speed index (Edmond and Drapala, 1958), and artificial aging at $41^{\circ} \mathrm{C}$ for $96 \mathrm{~h}$.

In addition, amylase enzyme expression was analyzed using qRT-PCR. Thus, RNA was extracted from seeds in the lines with high and low physiological quality, from their hybrid, and from the reciprocal hybrid, of 2 seed sizes, subjected to aging and not subjected to aging. The seeds were macerated in liquid nitrogen and Pure Link RNA Plant (Invitrogen, 
Carlsbad, CA, USA) was added following manufacturer specifications. RNA integrity was verified by $1 \%$ agarose gel electrophoresis and visualized after staining with ethidium bromide. Quantification of the RNA was carried out in a spectrophotometer at wavelengths of 260 and $280 \mathrm{~nm}$.

After nucleic acid extraction, the samples were treated with DNAse DNA Free (Ambion, Austin, TX, USA) to avoid DNA contamination, with procedures carried out following manufacturer recommendations. To verify the effectiveness of decontamination, a conventional PCR was conducted for all samples, which failed to amplify DNA. In this reaction, a sample of DNA of maize seeds and primers for the endogenous controls ubiquitin and alcohol dehydrogenase as positive controls. Amplification products were assessed by $1.5 \%$ agarose gel electrophoresis and stained with ethidium bromide.

After RNA extraction and purification, cDNA was synthesized using the High Capacity cDNA Reverse Transcription Kit from Applied Biosystems (Foster City, CA, USA) following manufacturer recommendations.

Gene expression was analyzed by qRT-PCR with primers designed using the Primer Express 3.0 software (Applied Biosystems) after searching for gene sequences on the site http://www.ncbi.nlm.nih.gov (Table 1). The ubiquitin and alcohol dehydrogenase genes were used as endogenous controls (Livak and Schmittgen, 2001; Scholdberg et al., 2009).

Table 1. Primers used for qRT-PCR analysis of seeds of different maize lines.

\begin{tabular}{lll}
\hline Gene & & Sequence $\left(5^{\prime}-3^{\prime}\right)$ \\
\hline Alpha amylase B73 & $\mathrm{F}$ & CCGGCTCCACGCAGAAC \\
Alpha amylase (LOC542522) & $\mathrm{R}$ & TATAGGCGTAGCCCTGCATGA \\
& $\mathrm{F}$ & TGCAGCCTCCTAGTGCTTGTAC \\
Isoamylase mRNA clone 353244 & $\mathrm{R}$ & TGGAAGAGGACCTGGGATTG \\
Ubiquitin & $\mathrm{F}$ & CATGAAGGACGAAACCAAAGG \\
Alcohol dehydrogenase (ADH) & $\mathrm{R}$ & TCTGGAAGCCCAACAACCA \\
& $\mathrm{F}$ & AAGGCCAAGATCCAGGACAA \\
& $\mathrm{R}$ & TTGCTTTCCAGCGAAGATGA \\
\hline
\end{tabular}

Sequence of the forward (F) primer and sequence of the reverse (R) primer.

To quantitatively analyze gene expression by qRT-PCR, an ABI PRISM 7500 RealTime PCR apparatus was used (Applied Biosystems) with the SYBR Green detection system. cDNA was obtained from RNA extracted from the seeds. The thermal conditions of the reaction were $2 \mathrm{~min}$ at $50^{\circ} \mathrm{C} ; 10 \mathrm{~min}$ at $95^{\circ} \mathrm{C}$; followed by 40 cycles for $15 \mathrm{~s}$ at $95^{\circ} \mathrm{C}$ and $1 \mathrm{~min}$ at $60^{\circ} \mathrm{C}$; and finally, $15 \mathrm{~s}$ at $95^{\circ} \mathrm{C}$. Data were obtained and stored in the program 7500 Software (Version 2.0.1). For each reaction, we used $1.0 \mu \mathrm{L}$ cDNA diluted 1:5, $0.2 \mu \mathrm{L}$ of each primer, and 5.0 $\mu \mathrm{L}$ Master Mix SYBR green UDG with ROX (Invitrogen) for a final volume of 10.0 $\mu \mathrm{L}$. Negative controls and melting curves were included in all analyses.

Three technical replicates were used for each gene examined, and the results were normalized using the $\mathrm{Ct}$ (threshold cycle) obtained based on the expression of the reference genes ubiquitin and alcohol dehydrogenase. $\mathrm{Ct}$ was determined based on the number of cycles in which the fluorescence generated within a reaction crossed the baseline (threshold). The comparative cycle threshold method was used. A validation experiment was first carried out to verify that the efficiencies of amplification of the target genes and reference genes were similar and close to $100 \%$. Standard curves for the genes under study were generated from the 
following dilutions: 1:5, 1:25, 1:125, 1:625, and 1:3125. This procedure also allowed identification of the best dilution of cDNA used in each reaction, which was 1:5.

The samples showing the lowest expression for each gene were used as calibration samples. The relative standard curve method, described in the manual of the device (Applied Biosystems), was used to measure relative expression. To quantify gene expression using realtime PCR, the values obtained corresponding to the mRNA levels of the samples were compared to control mRNA levels. Crude data were analyzed using the program 7500 Software SDS (Version 2.0.1). To calculate the expression level of the genes of interest, the following were considered: $\mathrm{Ct}$ (exponential increase in the PCR product) of the target gene and endogenous control, $\Delta \mathrm{Ct}=\mathrm{Ct}$ (sample) - $\mathrm{Ct}$ (endogenous control) and the $\Delta \Delta \mathrm{Ct}=\Delta \mathrm{Ct}$ (sample) $-\Delta \mathrm{Ct}$ (calibrator). Next, the expression level was calculated using the formula: $\mathrm{RQ}=2^{-\Delta \Delta \mathrm{Ct}}$.

To analyze physiological quality test results, a completely randomized design in a $4 \times 2 \times 2$ factorial arrangement was used, consisting of 4 genotypes ( 2 lines and 2 hybrids), subjected to aging and not subjected to aging, and 2 seed sizes with 4 replications. Mean values of the treatments for the tests were compared using the Scott and Knott test at the level of 5\% probability. Analyses were conducted using the statistical program R 2.14.1 (R Development Core Team, 2008).

\section{RESULTS}

Based on the analysis of variance results for the data obtained in the tests of germination, first germination count, artificial aging, emergence, and emergence speed index (Table $2)$, there was a significant effect $(\mathrm{P}=0)$, for the triple interaction among the genotype $\mathrm{x}$ aging $\mathrm{x}$ size factors. The breakdown of the genotype factor was made within the combination of the aging and size factors. The mean values of the data obtained are shown in Tables 3 and 4, together with their groupings based on the Scott and Knott test at the level of 5\% probability.

Table 2. Summary of analysis of variance of the data obtained in the test of germination, first germination count (FGC), accelerated aging test (AAT), seedling emergence, and emergence speed index (ESI) of the maize seeds of 4 genotypes, of 2 sizes (small and large), and 2 types of aging (subjected to aging and not subjected to aging).

\begin{tabular}{|c|c|c|c|c|c|c|}
\hline \multirow[t]{2}{*}{ Factors } & \multirow[t]{2}{*}{ d.f. } & \multicolumn{5}{|c|}{ MS } \\
\hline & & Germination & FGC & AAT & Emergence & ESI \\
\hline Genotype & 3 & $1290.8333 * *$ & $8501.4166^{* *}$ & $5.1219 * *$ & $1992.7291 * *$ & $2451.5625^{* *}$ \\
\hline Aging & 1 & $29756.2500 * *$ & $36864.0000 * *$ & $13.6166^{* *}$ & $20952.5625^{* *}$ & $10972.5625 * *$ \\
\hline Size & 1 & 56.2500 & 1.0000 & 0.1445 & 10.5625 & $315.0625^{* *}$ \\
\hline Genotype*Aging & 3 & $1074.4166^{* *}$ & $949.5000 * *$ & $0.5291 * *$ & $913.7291 * *$ & $316.0625^{* *}$ \\
\hline Genotype*Size & 3 & $817.4166^{* *}$ & $721.5000^{* *}$ & $0.3790 * *$ & $936.0625^{* *}$ & $274.5625^{* *}$ \\
\hline Aging*Size & 1 & $144.0000^{*}$ & 20.2500 & 0.0079 & 76.5625 & $175.5625^{*}$ \\
\hline Genotype*Aging*Size & 3 & $1096.1666^{* *}$ & $788.4166^{* *}$ & $0.2271^{* *}$ & $1081.7291 * *$ & $4580.7292^{* *}$ \\
\hline Residuals & 48 & 29.7916 & 23.9166 & 0.0483 & 39.2708 & 35.8125 \\
\hline $\mathrm{CV}(\%)$ & & 6.7 & 7.4 & 8.8 & 8.2 & 9.1 \\
\hline
\end{tabular}

*Significant at the level of $5 \%$ probability by the F-test. **Significant at the level of $1 \%$ probability by the F-test.

During the germination test period, samples were assessed at 4 days (first germination count) and at 7 days (germination) to determine the behavior of the genotypes throughout the germination process. Lower values of germination at 4 and 7 days were observed in the seeds of line P2 defined by the company as showing low physiological quality, particularly when they were subjected to aging (Table 3 ). 
Hybrid seeds $\left(\mathrm{F}_{1 \times 2}\right.$ and $\left.\mathrm{F} 1_{2 \times 1}\right)$ exhibited germination results superior to those of the parents in most of the combinations of factors, except at 7 days for seeds not subjected to aging, in which there was no significant difference among the genotypes (Table 3) and low values of heterosis (Table 4). It was also observed that the hybrid seeds showed greater speed during germination by comparing the germination percentages on the 4th day (Table 5).

Table 3. Mean results (\%) of the germination and first germination count (FGC) tests of maize seeds of 4 genotypes, of 2 sizes (small and large), and 2 types of aging (subjected to aging and not subjected to aging).

\begin{tabular}{|c|c|c|c|c|c|c|c|c|}
\hline \multirow[t]{3}{*}{ Genotypes } & \multicolumn{4}{|c|}{ Germination } & \multicolumn{4}{|c|}{ FGC } \\
\hline & \multicolumn{2}{|c|}{ Large seed } & \multicolumn{2}{|c|}{ Small seed } & \multicolumn{2}{|c|}{ Large seed } & \multicolumn{2}{|c|}{ Small seed } \\
\hline & Non-aged & Aged & Non-aged & Aged & Non-aged & Aged & Non-aged & Aged \\
\hline P1 & $95.0^{\mathrm{A}}$ & $56.0^{\mathrm{B}}$ & $96.5^{\mathrm{A}}$ & $46.0^{\mathrm{B}}$ & $87.0^{\mathrm{B}}$ & $36.5^{\mathrm{B}}$ & $87.0^{\mathrm{B}}$ & $17.5^{\mathrm{B}}$ \\
\hline P2 & $98.0^{\mathrm{A}}$ & $38.5^{\mathrm{C}}$ & $96.5^{\mathrm{A}}$ & $30.5^{\mathrm{C}}$ & $46.0^{\mathrm{C}}$ & $9.0^{\mathrm{C}}$ & $47.0^{\mathrm{C}}$ & $4.0^{\mathrm{C}}$ \\
\hline $\mathrm{F} 1_{1 \times 2}$ & $99.5^{\mathrm{A}}$ & $78.5^{\mathrm{A}}$ & $95.5^{\mathrm{A}}$ & $75.0^{\mathrm{A}}$ & $95.5^{\mathrm{A}}$ & $74.5^{\mathrm{A}}$ & $95.5^{\mathrm{A}}$ & $53.0^{\mathrm{A}}$ \\
\hline $\mathrm{F} 1_{2 \times 1}$ & $98.5^{\mathrm{A}}$ & $83.5^{\mathrm{A}}$ & $98.0^{\mathrm{A}}$ & $74.5^{\mathrm{A}}$ & $95.5^{\mathrm{A}}$ & $76.5^{\mathrm{A}}$ & $95.5^{\mathrm{A}}$ & $56.5^{\mathrm{A}}$ \\
\hline
\end{tabular}

*Mean values followed by the same uppercase letter in the column for each combination of the aging and size factors belong to the same grouping from the Scott and Knott test at 5\% probability.

Table 4. Results of heterosis in relation to the mean value of the parents (MP $=100 \%)$ for the tests of germination, first germination count (FGC), accelerated aging test (AAT), seedling emergence, and emergence speed index (ESI) of the maize seeds of 4 genotypes, of 2 sizes (small and large), and 2 types of aging (subjected to aging - A, and not subjected to aging - NA).

\begin{tabular}{|c|c|c|c|c|c|c|c|c|}
\hline \multirow[t]{3}{*}{ Heterosis } & \multicolumn{4}{|c|}{$\mathrm{F} 1_{1 \times 2}$} & \multicolumn{4}{|c|}{$\mathrm{F} 1_{2 \times 1}$} \\
\hline & \multicolumn{2}{|c|}{ Large seed } & \multicolumn{2}{|c|}{ Small seed } & \multicolumn{2}{|c|}{ Large seed } & \multicolumn{2}{|c|}{ Small seed } \\
\hline & NA & A & NA & A & NA & A & NA & A \\
\hline Germination & 103 & 166 & 99 & 184 & 102 & 177 & 102 & 183 \\
\hline FGC & 144 & 327 & 149 & 493 & 144 & 336 & 149 & 526 \\
\hline AAT & 246 & 1000 & 395 & 820 & 146 & 1120 & 419 & 320 \\
\hline Emergence & 103 & 154 & 101 & 191 & 106 & 163 & 107 & 187 \\
\hline ESI & 110 & 109 & 114 & 117 & 112 & 125 & 110 & 116 \\
\hline
\end{tabular}

Table 5. Mean results (\%) of vigor obtained by the accelerated aging test (AAT), seedling emergence, and emergence speed index (ESI) of maize seeds from 4 genotypes, of 2 sizes (small - SS, and large - LS), and subjected to aging and not subjected to aging (A and NA).

\begin{tabular}{|c|c|c|c|c|c|c|c|c|c|c|c|c|}
\hline \multirow[t]{3}{*}{ Genotype } & \multicolumn{4}{|c|}{ AAT } & \multicolumn{4}{|c|}{ Emergence } & \multicolumn{4}{|c|}{ ESI } \\
\hline & \multicolumn{2}{|c|}{ LS } & \multicolumn{2}{|c|}{ SS } & \multicolumn{2}{|c|}{ LS } & \multicolumn{2}{|c|}{ SS } & \multicolumn{2}{|c|}{ LS } & \multicolumn{2}{|c|}{ SS } \\
\hline & NA & A & NA & A & NA & A & NA & A & NA & A & NA & A \\
\hline P1 & $29^{c}$ & $3^{\mathrm{B}}$ & $19.5^{\mathrm{B}}$ & $6.5^{\mathrm{C}}$ & $91.0^{\mathrm{A}}$ & $52.5^{\mathrm{B}}$ & $90.5^{\mathrm{A}}$ & $24.5^{\mathrm{C}}$ & $6.0^{\mathrm{B}}$ & $6.49^{C}$ & $5.78^{\mathrm{B}}$ & $6.69^{c}$ \\
\hline P2 & $23^{c}$ & $2^{\mathrm{B}}$ & $17.0^{\mathrm{B}}$ & $3.5^{\mathrm{C}}$ & $97.5^{\mathrm{A}}$ & $56.5^{\mathrm{B}}$ & $96.0^{\mathrm{A}}$ & $60.0^{\mathrm{B}}$ & $4.56^{\mathrm{A}}$ & $6.21^{\mathrm{C}}$ & $4.56^{\mathrm{A}}$ & $5.88^{\mathrm{B}}$ \\
\hline $\mathrm{F}_{1 \times 2}$ & $64^{\mathrm{A}}$ & $25^{\mathrm{A}}$ & $72.0^{A}$ & $41.0^{A}$ & $97.0^{\mathrm{A}}$ & $84.0^{\mathrm{A}}$ & $94.0^{\mathrm{A}}$ & $80.5^{\mathrm{A}}$ & $4.78^{\mathrm{A}}$ & $5.81^{\mathrm{B}}$ & $4.55^{\mathrm{A}}$ & $5.37^{\mathrm{A}}$ \\
\hline $\mathrm{F}_{2 \times 1}^{1 \times 2}$ & $38^{\mathrm{B}}$ & $28^{\mathrm{A}}$ & $76.5^{\mathrm{A}}$ & $16.0^{\mathrm{B}}$ & $100.0^{\mathrm{A}}$ & $89.0^{\mathrm{A}}$ & $99.5^{\mathrm{A}}$ & $79.0^{\mathrm{A}}$ & $4.70^{A}$ & $5.06^{\mathrm{A}}$ & $4.68^{\mathrm{A}}$ & $5.41^{\mathrm{A}}$ \\
\hline
\end{tabular}

* Mean values followed by the same uppercase letter in the column for each combination of the aging and size factors belong to the same grouping by the Scott and Knott test at 5\% probability.

The P1 showed greater results for germination than P2 at 4 and 7 days. These results were in agreement with the data presented by the company, which identified P1 as having low physiological seed quality. 
As shown in Table 5, in the artificial aging test, greater vigor of the hybrid seeds was observed compared to seeds in the parental lines. Additionally, large seeds of the $\mathrm{F} 1_{1 \times 2}$ hybrid not subjected to aging and small seeds subjected to aging exhibited greater vigor than those from the $\mathrm{F} 1_{2 \times 1}$ hybrid, thus presenting a maternal effect for this characteristic. For the seedling emergence test, the seeds not subjected to aging of the 4 genotypes did not differ among themselves. For seeds subjected to aging, lower values were observed in seeds of the parental lines.

The results of the emergence speed index provided the average number of days to emergence; therefore, the P1 seeds showed lower performance, i.e., a greater number of days to emerge compared to that in other genotypes, regardless of the combination of other factors. For seeds not subjected to aging, there was no significant difference between P2 seeds and hybrid seeds, whereas seeds subjected to aging, showed better performance for the hybrid seeds.

In general, tests used to assess physiological quality (Tables 3 and 5) showed lower values of germination and vigor in seeds from the parental lines (P1 and P2); seeds not subjected to aging showed better performance than those subjected to aging. Thus, hybrid seeds showed better physiological quality.

From the results of the heterosis test (Table 4), greater values of heterosis were observed for the accelerated aging test and 1st germination count. Notably, the greatest values of heterosis were observed in seeds subjected to aging, regardless of the test performed.

In Figure 1, greater expression of the $A m y B 73$ gene was observed in the hybrid seeds, particularly when they were classified as large. This behavior was also observed for the alpha amylase gene (LOC542522) (Figure 2).

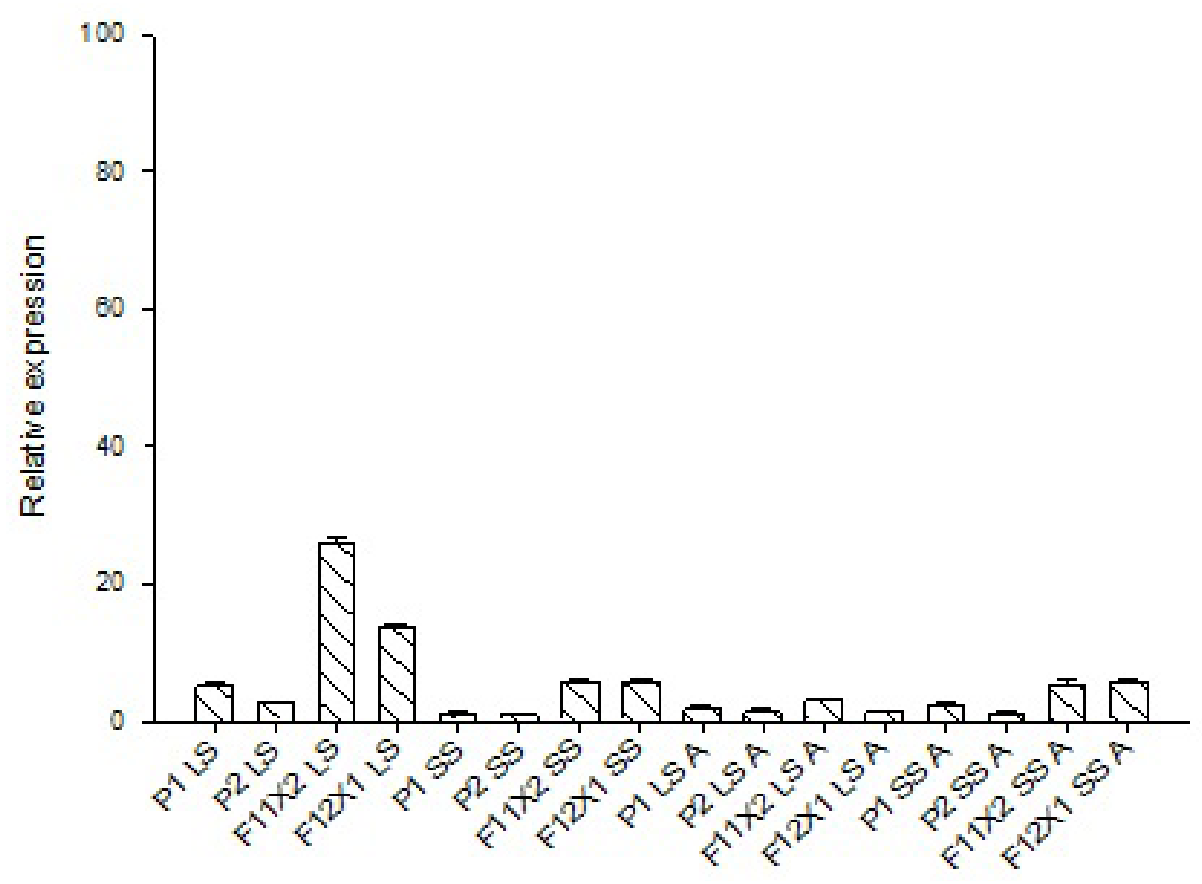

Figure 1. Profile of the relative quantitative expression of the gene alpha amylase B73 (AmyB73) in seeds of 2 lines $(\mathrm{P} 1$ and $\mathrm{P} 2)$ and 2 hybrids $\left(\mathrm{F}_{1 \times 2}\right.$ and $\left.\mathrm{F} 1_{2 \times 1}\right)$ of maize, of small seeds (SS) and large seeds (LS), subjected to aging (A) and not subjected to aging. 


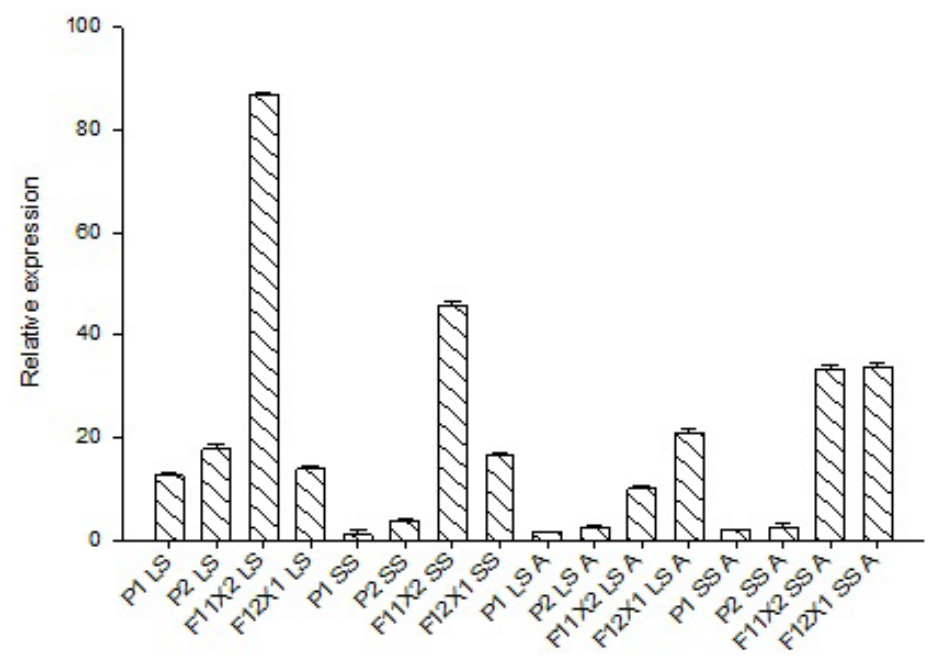

Figure 2. Profile of the relative quantitative expression of the gene alpha amylase (LOC542522), in seeds of 2 lines ( $\mathrm{P} 1$ and $\mathrm{P} 2)$ and 2 hybrids $\left(\mathrm{F} 1_{1 \times 2}\right.$ and $\left.\mathrm{F}_{2 \times 1}\right)$ of maize, of small seeds (SS) and large seeds (LS), subjected to aging (A) and not subjected to aging.

Compared to the gene isoamylase clone 353244 (IsoAmy) (Figure 3), greater expression was observed in seeds not subjected to aging, and the same results were observed in the germination and vigor tests. Thus, expression of this gene may be related to the physiological quality of seeds at the beginning of storage. It may also be observed that for large seeds not subjected to aging, there was greater expression in $\mathrm{F} 1_{1 \times 2}$ hybrid seeds, whereas for small seeds not subjected to aging, greater expression was observed for the $\mathrm{F} 1_{2 \times 1}$ hybrid.

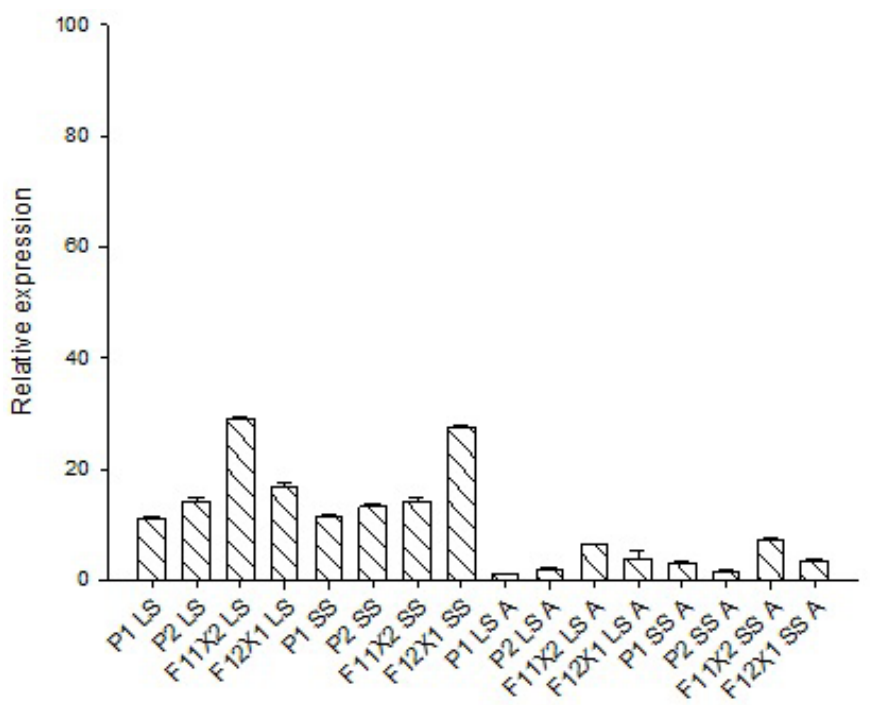

Figure 3. Profile of the relative quantitative expression of the gene isoamylase clone 353244 (IsoAmy) in seeds of 2 lines (P1 and P2) and 2 hybrids $\left(\mathrm{F}_{1 \times 2}\right.$ and $\left.\mathrm{F} 1_{2 \times 1}\right)$ of maize, of small seeds (SS) and large seeds (LS), subjected to aging (A) and not subjected to aging. 


\section{DISCUSSION}

In the germination test (Table 3), no significant difference was observed between the hybrids and the parents of seeds not subjected to aging. This may be because of the favorable environmental conditions used during seed production; according to José et al. (2004) and Silva et al. (2008), various genes control the physiological quality of maize seeds. Therefore, it is necessary to produce seeds in different locations as conditions used during the seed production process may interfere with the behavior of the genotype regarding seed physiological quality.

In general, in the germination test, aged seeds showed lower germination values than non-aged seeds, and large seeds showed better results than small seeds. However, it is important to emphasize that because of the triple interaction between the factors, conclusions should be considered with caution given the complexity of the interaction.

Based on the results of the accelerated aging test (Table 5), less vigor was observed in seeds from parent lines, and the greatest values of heterosis were observed for this test (Table 4). These results agreed with those of Gomes et al. (2000) who observed heterosis related to the accelerated aging test, showing that hybrid seeds exhibited storage potential that was greater than that in seeds from lines. Notably, for the accelerated aging test, there was a significant difference between the hybrid and the reciprocal hybrid, and a maternal effect was observed. This may also be related to the germination test, in which there was a significant difference between the parents.

The aging factor was included in the experiment to simulate aging during storage, as seed-producing companies are limited by the shelf-life of seeds from lines, significantly increasing the cost of production as it is necessary to multiply the seeds more frequently. This can easily be observed when comparing heterosis values (Table 4).

According to the results of all tests, there was no consistency in the comparisons between seed sizes, corroborating the results of Andrade et al. (1997) and Nafziguer (1992). Moreover, these authors concluded that maize seed size and shape does not significantly affect grain production.

Comparing the physiological tests and the expression of the AmyB73 and alpha amylase (LOC542522) genes (Figure 1 and 2), agreement was observed in the results, indicating the superiority of the hybrids compared to the parents. In addition, a maternal effect was observed for expression of the alpha amylase (LOC542522) gene because seeds of the $\mathrm{F} 1_{1 \times 2}$ hybrid not subjected to aging showed greater expression of this gene compared to the reciprocal hybrid, as was observed in the accelerated aging test.

Oliveira et al. (2013) correlated the expression of the genes AmyB73 and alpha amylase (LOC542522) with the physiological quality of soaked seeds of maize lines; in addition, they associated the expression of these genes with specific isoforms of the zymogram of $\alpha$-amylase using an electrophoresis test. These same authors did not observe expression of these genes in dry seeds, as enzymatic activity during the germination process was much higher. When the seeds were soaked, enzyme synthesis occurs de novo and expression was much greater (Less and Galili, 2008). Because quantification of gene expression using qRTPCR is comparative, in this study we observed expression in dry seeds as the expression of these genes was not compared to that in soaked seeds.

According to the results presented in this study, it was not possible to indicate one gene as the main factor of heterosis; what we are able to observe is an interaction of the factors, resulting in the heterosis observed. Similar results were observed by Fu et al. (2011), who 
compared proteomic analyses and heterosis during maize seed germination. These authors also concluded that heterosis in the hybrid results from the interaction between the effects of various proteins, which cannot be associated with only one protein.

Numerous studies have been sought to explain the genetic bases of heterosis, and some hypotheses have been proposed: the hypothesis of dominance, in which dominant factors of one of the parental lines mask the recessive alleles of the other parental line in the heterozygous F1, in gene complementation (Bruce, 1910); the hypothesis of overdominance, in which the heterozygous locus confers better performance than the homozygous locus (Shull, 1908); the hypothesis of "pseudo-overdominance", related to the deleterious alleles in homozygosis linked in repulsion or a trans-arrangement (Mangelsdorf and Gowen, 1952); and the hypothesis of epistasis, which refers to superiority of the non-allelic interaction in the heterozygous F1 (Goodnight and Queller, 1999).

Recently, with advances in molecular techniques, complementary theories have been proposed, including epigenetic modifications (Groszmann et al., 2013), variation in genome structure (Fu and Dooner, 2002; Song and Messing, 2003), protein-specific function, and posttranscriptional modification (Paschold et al., 2010; Liu et al., 2010; Guo et al., 2013), which have been related to the heterosis of specific tissues and stages of development. Nevertheless, most studies were carried out using fully developed plants, and little is known regarding the genetic and molecular bases of heterosis; less is known about the relationship between heterosis and seed germination.

Heterosis was observed for seed quality and for amylase gene expression in the genotypes studied. Furthermore, no difference in seed quality between large and small seeds was observed, and a maternal effect for seed quality was observed.

\section{REFERENCES}

Andrade RV, Andreoli C, Borba CS, Azevedo JT, et al. (1997). Efeito da forma e do tamanho da semente no desempenho no campo de dois genótipos de milho. Rev. Bras. Sementes 19: 62-65.

Andrade T, Von Pinho EV, Von Pinho RG, Oliveira GE, et al. (2013). Physiological quality and gene expression related to heat-resistant proteins at different stages of development of maize seeds. Genet. Mol. Res. 12: 3630-3642.

Brasil (2009). Regras para Análise de Sementes, Ministério da Agricultura, Pecuária e Abastecimento, Brasília.

Bruce AB (1910). The Mendelian theory of heredity and the augmentation of vigor. Science 32: 627-628.

Ding D, Wang Y, Han M, Fu Z, et al. (2012). MicroRNA transcriptomic analysis of heterosis during maize seed germination. PLoS One 7: e39578.

Edmond JB and Drapala WJ (1958). The effects of temperature, sand and soil, and acetone on germination of okra seed. Proc. Am. Soc. Hort. Sci. 71: 428-434.

Fu H and Dooner HK (2002). Intraspecific violation of genetic colinearity and its implications in maize. Proc. Natl. Acad. Sci. U. S. A. 99: 9573-9578.

Fu Z, Jin X, Ding D, Li Y, et al. (2011). Proteomic analysis of heterosis during maize seed germination. Proteomics 11: $1462-1472$

Gomes MS, Von Pinho EVR, Von Pinho RG and Vieira MGGC (2000). Efeito da heterose na qualidade fisiológica de sementes de milho. Rev. Bras. Sementes 22: 7-17.

Goodnight KF and Queller DC (1999). Computer software for performing likelihood tests of pedigree relationship using genetic markers. Mol. Ecol. 8: 1231-1234.

Groszmann M, Greaves IK, Fujimoto R, Peacock WJ, et al. (2013). The role of epigenetics in hybrid vigour. Trends Genet. 29: 684-690.

Guo B, Chen Y, Zhang G, Xing J, et al. (2013). Comparative proteomic analysis of embryos between a maize hybrid and its parental lines during early stages of seed germination. PLoS One 8: e65867.

Hallauer AR, Carena MJ and Miranda Filho JB (2010). Quantitative Genetics in Maize Breeding. 3rd edn. SpringerVerlag, Berlin. 
Hoecker N, Keller B, Piepho HP and Hochholdinger F (2006). Manifestation of heterosis during early maize (Zea mays L.) root development. Theor. Appl. Genet. 3: 421-429.

Jin X, Fu Z, Ding D, Li W, et al. (2014). Proteomic analysis of plumules and coleoptiles in maize between hybrids and their corresponding inbred lines. Acta Physiol. Plant. 36: 355-370.

José SCBR, Von Pinho EVR, Von Pinho RGV, Ramalho MAP, et al. (2004). Controle genético da tolerância à alta temperatura de secagem em sementes de milho. Rev. Bras. Milho Sorgo 3: 414-428.

Less $\mathrm{H}$ and Galili G (2008). Principal transcriptional programs regulating plant amino acid metabolism in response to abiotic stresses. Plant Physiol. 147: 316-330.

Li B, Zhang DF, Jia GQ, Dai JR, et al. (2009). Genome-wide comparisons of gene expression for yield heterosis in maize. Plant Mol. Biol. 27: 162-176.

Liu Y, Von Behrens I, Muthreich N, Schütz W, et al. (2010). Regulation of the pericycle proteome in maize (Zea mays L.) primary roots by RUM1 which is required for lateral root initiation. Eur. J. Cell Biol. 89: 236-241.

Livak KJ and Schmittgen TD (2001). Analysis of relative gene expression data using real-time quantitative PCR and the 2(-Delta Delta CT) Method. Methods 25: 402-408.

Mangelsdorf PC and Gowen JW (1952). Hybridization in the evolution of maize. In: Heterosis (Gowen JW, ed.). State College Press, Ames, 175-198.

Meyer S, Pospisil H, and Scholten S (2007). Heterosis associated gene expression in maize embryos 6 days after fertilization exhibits dominant and overdominant pattern. Plant Mol. Biol. 63: 381-391.

Nafziguer ED (1992). Seed size effects on yields of two corn hybrids. J. Prod. Agric. 4: 538-544.

Oliveira GE, Von Pinho RG, Andrade T, Von Pinho EVR, et al. (2013). Physiological quality and amylase enzyme expression in maize seeds. Ciênc. Agrotec. 37: 40-48.

Paleg LG (1965). Physiological effects of gibberellins. Ann. Rev. Plant Physiol. 16: 291-322.

Paschold A, Marcon C, Hoecker N and Hochholdinger F (2010). Molecular dissection of heterosis manifestation during early maize root development. Theor. Appl. Genet. 120: 383-388.

R Development Core Team (2008). R: A language and environment for statistical computing. R Foundation for Statistical Computing, Vienna. Available at [http://www.R-project.org]. Accessed October 22, 2011.

Rood SB and Larsen KM (1988). Gibberellins, amylase, and the onset of heterosis in maize seedlings. J. Exp. Bot. 39: 223-233.

Rood SB, Buzzell RI and Major DJ (1990). Gibberellins and heterosis in maize: quantitative relationships between GA content, GA3 response, and growth. Crop Sci. 30: 281-286.

Scholdberg TA, Norden TD, Nelson DD and Jenkins GR (2009). Evaluating precision and accuracy when quantifying different endogenous control reference genes in maize using real-time PCR. J. Agric. Food Chem. 57: 2903-2911.

Shull GF (1908). The composition of a Weld of maize. Am. Breed Assoc. Rep. 4: 296-301.

Silva NO, Ramalho MAP, Bruzi AT and Von Pinho EVR (2008). Genetic control of traits associated with maize seed quality. Maydica 53: 55-62.

Song R and Messing J (2003). Gene expression of a gene family in maize based on non-collinear haplotypes. Proc. Natl. Acad. Sci. U. S. A. 100: 9055-9060.

Von Pinho EVR, Silveira JF, Vieira MGGC and Fraga AC (1995). Influência do tamanho e do tratamento de semente de milho na preservação da qualidade durante o armazenamento e posterior comportamento no campo. Ciênc. Prática 19: 30-36. 